\title{
Culture: The Socio-Political Base of Ethnic Consciousness and Conflicts in Nigeria
}

\author{
Gregory Emeka Chinwuba \\ http://dx.doi./org/10.4314/ujah.v21i2.8
}

\begin{abstract}
Nigeria suffers conflicts whose causes are pinned on ethnic consciousness and factors other than culture. As such, culture is considered as an epiphenomenon. But at the base of Nigerian conflicts is culture which shapes and stirs ethnic consciousness, and remains a divisive factor in human societies. Thus, Nigeria is socio-politically polarized along cultural lines and conflicting cultural contents despite the present world of traversing cultural boundaries. This paper analytically exposes culture as the sociopolitical base of ethnic consciousness and conflicts in Nigeria, and reveals the philosophical foundation of cultural character as well as axiological panacea to conflicts in Nigeria. The paper finds that in every socio-political setting, ethnic consciousness does not happen in a vacuum, and nobody speaks and acts from nowhere but from a cultural orientation; for culture is the matrix of human existence and nothing happens outside it. As such, ethnic consciousness and human socio-political exercises; behaviours, dispositions and actions are shaped, posited, viewed and interpreted from cultural spaces. But to bridle the negative impact of culture and enhance national unity, consciousness and patriotism of the citizenry, the study concludes that there is need for a national culture that is replete with indigenous values and overlapping similarities to form the content of curriculum in Nigerian education system.
\end{abstract}


Keywords: Culture, socio-political, base, ethnic consciousness, conflict.

\section{Introduction}

Human socio-political thoughts, behaviours, practices and ethnic consciousness are shaped by cultural orientations, and cosmic realities are viewed and interpreted from cultural windows. As an indispensable fulcrum of existence, culture forms the interiority of the being of a people and subsequently shapes their existence (Patterson, 2000). As such, culture in Nigerian setting is the basis of ethnic homogeneity, consciousness, practices, disagreement and conflict. Cultural conflict is again more susceptible to Nigeria because of the country's cultural heterogeneity and ethnicity which is fertile in contradictory systems, values, understanding, sense of superiority and right that overshadow the few overlapping similarities among people. This condition is however exacerbated by the glaring fact that Nigeria roams in poor governance and leadership ineptitude, lacking functional institutions that suppose to checkmate cultural excesses and cushion the effects of cultural relations and diffusion.

As such, 'One Nigeria' orientation meant to integrate the populace has yielded no result; for many cultural nations in Nigeria have continued to treat other ethnic groups as inferior strangers, who must share no equal socio-political and economic rights with them. Even among homogenous cultural groups, culture is also the basis of conflict. Such conflict often stems from degrees of consciousness or zealousness over certain cultural aspects, different interpretation or understanding of cultural elements and practices, as well as the promotion or abrogation of certain cultural tenets by indigenous conservatives and liberals. Along this line, cultural diffusion characterizing homogenous Nigerian cultures 
also results to conflict. This is as such diffusion truncates the ties of the community, harmonious interiority of the being of the individuals in the community, internal equilibrium of personhood and autochthonous essence that derives from stable communally appreciated cultural values (Odimegwu, 2008). Against these unending conflict orienting conditions in Nigeria, ethnic consciousness and several factors other than culture have been wrongly considered. As such, this treatise tends to expose culture as that broad phenomenon which underscores human thoughts, dispositions, actions, ethnic consciousness and conflicts, and which deserves critical consideration so as to reduce its conflict effects in Nigeria and global human society.

\section{Conceptual Analysis}

Words can conceal or deliver ambiguous information. Thus, unexplained concepts are largely misnomers that obstruct understanding and knowledge. But clarified concepts reveal the meanings lurking in words and enhance human understanding. This is why there is great need to clarify culture, ethnic consciousness and conflict which are outstanding concepts in this discourse. Culture is not the general activities that pervade human existence, but the mode applied by specific people in cosmic activities. Thus, food and marriage are general phenomena among human beings but how a people make and eat food or marry form part and parcel of their culture.

Culture therefore bothers more on 'how' a people do things and not mainly on 'what' they do. This 'how' points at the peculiar processes in-between the agents and an end. The 'how' that makes culture comprises of explicit and tacit assumptions and understanding commonly held by a group of people, which serve as guides to their actions, and accords them ground for survival 
((Ugwu, 2012, Aghamelu, 2005). Though culture is shaped by people's experiences in the environment, it turns to form the deep seated beliefs that are behind people's choices, how they think, their consciousness, character, orientation, belief, art, customs, attitudes, music, literature, social, political, ethical, intellectual, scientific, artistic, technological expressions and processes ((Ezeugwu, 2012), Olukaode, 2009).Culture is therefore the philosophical assumptions underlying human values, customs, social relations, ethnic consciousness and overall outlooks on life (Huntington, 1996). Hence, Ogbu (1983) describes it as a people's unified picture of the cosmos explained by a system of concepts which order their natural and social rhythms and the place of individuals in the world.

Nevertheless, ethnic consciousness is an overt, deliberate or conscious promotion of cultural convictions, projection of tribal relevance and seeking of recognition or domination in national matters by a particular ethnic group. In this sense, ethnic consciousness connotes awareness and display of sentiments; thoughts, feelings, senses and uniqueness by people that come from a particular locality and have common characteristics, cultural identity and heritage. These are why Ayatse and Akuva (2013) describe ethnic consciousness as consciousness of belonging to, identifying with, and being loyal to a social group distinguished by cultural tradition; common language, in-group sentiment and self identity. This consciousness becomes glaring when this in-group allows their ethnic conviction and contents such as cultural sentiments; thoughts, feeling, senses, ties and uniqueness to manifest in the way they relate to others.

Ethnic consciousness is also a unique cultural group behaviour seeking for favour restrictive to its group members (Ayatse \& Akuva, 2013). Thus, ethnic consciousness is a display 
of sentiments from a cultural group in approval or disapproval of matters that affect them in the wider society. From these viewpoints, it stands that ethnic consciousness does not emanate from a vacuum. For, cultural elements and orientations stir, inform, shape and propel it. Hence, ethnic consciousness is a cultural consciousness. This is more so as it is replete with projection and defense of cultural convictions and sentiments; values, norms, ethos, thoughts, feeling, senses, ties, uniqueness as well as displaying of ethnic affinity and allegiance.

Conflict however is a violent disagreement or clash between two opposing groups. It is any discord resulting from almost every aspect of social situations (Ho-Won, 2008). Conflict occurs when opposing groups within a society contend something that is important to them (Ejeh, 2012). Thus, conflict emanates from pursuit of incompatible interests, goals and values by different groups. As such, it is understood as a violent condition underscored by divergent ideas, opinions, feelings and wishes mostly informed by cultural experiences. Conflict is therefore an overt struggle among persons or parties that degenerate to neutralizing, injuring or (in extreme cases) eliminating rivals in order to gain an advantage (Obaditan, 2003).

\section{Cradle and Essence of Culture}

Man's innate ability to reason makes him a being with higher grade of existence. This rational ability enables man to perceive and interpret his peculiar environment, have a worldview, and assign meaning to his being, realities, activities and events around him (Oguejiofor, 2009). These perceptions, meaning and worldview are what the progenitors articulate as culture, which is discernible from customs and traditions that are visible in religious beliefs, rituals, festivals, norms, language, myths and folklores 
(Bamikole, 2008). Thus, ethnic progenitors coined culture in pristine time through their experiences in their environment, and taught it to their offspring who transmit it from generation to generation for their survival (Ekiyor, 2007). Based on this, culture is not only an unnatural phenomenon but an integral system of learned behaviour patterns, characterized by individuation, stemming not from biological inheritance, but from people's encounter with their environment and manifests in the behaviour and consciousness of such people (Berger, 2002, Kanu, 2010).

In line with this evolution, essence of culture revolves around the modes of practices or processes of human groups which differentiates them from others. These modes could be visible in thoughts, character, productions, ethics, religion, arts, sociopolitical structures and relation peculiar to the people. The substance of culture also extends to its capacity to undergo constant dialectics through its encounter with internal and external agents. Thus, culture has an inevitable confrontation from change resulting to it being created and inherited. This happens as each generation leaves her footprints on the sands of time by confronting her cultural heritage, and in that confrontation creates her own tradition that accompanies their heritage (Ogbu, 1975). Adding to this essence however; is that culture is characterized by openness and dynamism which give rise to quantitative and qualitative changes in the socio-political dimensions of human society.

Within the natural change in culture is also persistent permanence. This is based on the reality that things or phenomenon naturally change and take on different forms, but they contain something which remains constant throughout the flux of change (Stumpf, 1994). While maintaining elements of continuity therefore, culture only derail significantly from what it was one or 
two generations previously (Huntington, 1991). Consequently, culture in essence is identity. It acts as a Siamese with a people whom it clothes with a halo (its contents), and forms the ground and capacity of their consciousness and continuous existence and exploitation of opportunities in the world.

Adding to the essence of culture moreover are its constitutive and regulative functions reflecting in its capacity to shape human thought, behaviour and society as well as its embodiment of norms and ethos that enhance these functions (DiMaggio, 2000). Thus, culture as an integral system possesses an explicative and regulatory character, and performs adaptive and integrative roles in human society (Michael, 2008). This is why Odimegwu (2006) opines that culture is a way of life of a people that tells their way of 'being' and determines even their way of dying. Generally therefore, the nature of culture consists in cognitive processes which structure the thinking and mindset of a people, linguistic forms through which a particular people communicate and express their ideas; aesthetic character through which a people's feelings and thoughts manifest and socio-political structure which governs their relationship in the society (Anikwe, 2014).

\section{Assumed Basis of Conflicts in Nigeria}

Some scholars argue that marginalization, socio-economic and political discrimination as well as ethnic consciousness are sources of conflicts in Nigeria (Senghas, 2002). Thus, conflict according to them erupts, when the marginalized cultural nations become conscious of their deprivations and seek an equal share of national income, economic opportunities, political recognition or social development as well as when they become conscious of their area of habitat. Proponents of this school of thought therefore believe 
that multi-cultural societies only experience conflict of distribution and defense of geographical areas. This viewpoint also implies that conflicts in Nigeria are mere acts of agitation for recognition, absence of anticipated life prospects and dividends, as well as desperation and defense emerging from invasion or encroachment of hostile groups. However, only a cultural people can feel neglected, marginalized or discriminated when the aforementioned socio-political and economic conditions have implicative meaning in their culture. And only a cultural people can be conscious of their geographical location and boundaries as well as the need to defend it. As such, ethnic consciousness and people's idea of socio-politics and economics; fair distribution of resources cannot be divorced from their cultural orientations, which are largely the basis of human sentiments, thoughts, behaviours, actions, social views, understanding and interpretation of socio-political and economic issues. More obviously, ethnic consciousness and human sense of inequality does not happen in a vacuum but are spurred, strengthened, interpreted and understood in cultural contexts.

Some scholars however argue that conflict emanates from conflicting interests (Ejeh, 2012). Yet, human interest or dispositions; likes and dislikes are also culturally contextual. Along this line, cultural orientations largely determine human interests. This is because people form ideas, interests or dispositions from materials and orientations supplied from cultural environments (Chinweuba \& Ezeugwu, 2016). Another assumed source of conflict posited by scholars is differences in sociopolitical and economic ideologies held by diverse people or groups within the society. A critical investigation however shows that human ideologies are not separate from culture for they are products of culture. In this sense, Omazu (2010) concurs that people's ideologies and their mode of governance are not different 
from their culture and civilization. Thus, the ideology of people and their form of political, religious, economic and institutional organization are indispensable constituents or parts of cultural variables, identity and civilization.

Some thinkers also view religious differences as causes of conflict in Nigeria (Oforegbu, 2014). But, religion is also a variable that emanate from culture. Thus, the present clash between Christianity, Islam and Traditional Religion in Nigeria is simply a re-enactment of the age long clash of western, Arab and African traditional cultures that serve as sources of these creeds. Other assumed basis of conflict in Nigeria bothers on theological and psycho-biological determinism. The theological determinists assert that humans are irresistibly directed by supernatural forces (Arua, 2007). This assertion presents humans as mere material beings incapable of thinking and willing. However, the fact that proponents of this assumption have not rationally proven the sequences; how, where and when of this supernatural cosmic control as well as the ground of human responsibility in the universe nullifies their claim. Hence, the world still prescribes responsibilities of actions to human agents. Driven by psychobiological understanding, Hobbes (1985) submits that humans are deterministically propelled to abnormal motions of will, appetite and aversion which are visible in cosmic competition, diffidence and glory that results to enmity and conflict. Other psychobiological determinists however point at endocrine glands and genes as determinants of human conducts. A critical investigation however reveals that psycho-biological factors only confer personal characters on individuals, a character inherited from one's lineage. Such character is not general in a people and do not affect or drive the behaviour of an ethnic group in a significant way as culture generally does. Thus, the conflicts brought by psycho- 
biological factors are personal and not general as that brought by culture which largely involves an ethnic group.

\section{Culture: The Socio-Political Base of Ethnic Consciousness and Conflicts in Nigeria}

From the discourse so far, it stands that culture is the catalyst behind major conflicts in Nigeria. Among homogenous people, such conflict is often between conservatives and liberals of cultural tenets. This is as conservatives fanatically oppose the liberal human natural openness to change and alteration of cultural traditions and customs (Chinweuba \& Ezeugwu, 2018). However, cultural diffusion and change has broken traditions and practices that form the fulcrum of internal equilibrium and psychic coordination of the individual and the community. The dire effect is the increasing crisis of being, identity and personhood among the citizenry, which increases their frustration and spurs them to violent conflict.

In Nigeria, tribalism is glaring as people largely identify with their cultural groups, and politics is even played along cultural lines and bias (Obatala, 2014). This cultural consciousness batters nationalism, patriotism and integration leading to habitual sabotage of national interest, escalating tension and conflict (Nze, 2007). Along this line, Nigeria is replete with cultural divisive notion of "us" as superior and "them" as inferior which paves way for cultural hegemony and stiff resistance. Adding to these are cultural differences replete in contradictory and provocative value systems and religious experiences. These cultures in fact advance diverse versions of what is right and what is wrong, who is right and who is wrong which are answered based on cultural stipulations. Based on these, what is right for a cultural group may be ethically wrong for another (Nwozuzu 2011). And some actions 
are frowned at when it involves one's people but regarded as a virtue when it involves strangers or 'infidels' (Amunnadi, 2012). In fact, the resentment of Nigerian cultural groups against each other is so pronounced that at every provocation, each group threatens secession or the existence of others (Nwokolo \& Ogenyi, 2011).

In Nigeria still, the state creates social inequality that provokes conflict through its practices that recognize some ethnic cultural contents more than those of others. These state practices are glaring in its adoption of particular religious observances, language and other ethno-cultural practices during state functions. It is also visible in political appointments and distribution of commonwealth which favours some cultural groups more than others. This is exacerbated by symbols of the state, naming conventions (of buildings, roads, streets, centers, etc) and recognition of national heroes and histories that are not evenly distributed among all cultural groups. These social and political imbalances of course, signal the dominance of the cultural groups that own these practices and their full inclusion in the society's administration (UNDP, 2004). It however stirs deep resentment and ethnic consciousness in other cultural groups who feel symbolically excluded and disadvantaged in the state administration. Langer (2005) however documents that such lopsidedness in state's practices also creates an explosive situation as political elites usually hijack the situation, and mobilize their supporters for violent conflict along cultural lines with the aim of gaining prominence in their constituencies.

Besides, insufficient recognition of cultural groups by Nigeria government also causes conflict. And equal inclusion of cultural practices in the state administration again leads to conflicting multiple mode of living that is detrimental to the 
society. However, attempt by the state to remain neutral in recognizing cultural values and practices mars quality administration and leads to cluelessness and ineptitude. It therefore stands that with unitary government in multi-cultural societies like Nigeria, the state would never recognize the cultural groups equally. Thus, Government policies, implementation and day to day administration would in one way or the other accord inferior or superior status to certain cultural practices. Consequently, the alienated cultural groups mobilize themselves violently along cultural lines to assert their relevance.

\section{Impact of Culture in Nigerian Existence}

The impact of culture in Nigerian existence is deeper than most scholars think. And with the present globalized world, modernism and information and communication technology (ICT), there has been enhanced social practice in which other cultures exert influences on many individuals. Thus, many people are not only shaped by their culture of origin but by other cultures through association. Evidently therefore, these cultures are the catalysts, spaces and bounds for expression and existence of peoples within Nigerian communities (Michael 2008). They are too the main sources of human character, motivation, power and display. This is as these cultures underlies human thoughts, orientations, attitudes, beliefs, assumptions, values, and thereby shape people's definition, patterns of cohesion, disintegration and conflict (Huntington 2003).

Impact of culture in human beings is so pronounced that we may explicitly formulate theories or model, and consciously use them to guide our behaviour. We may also assume to be acting objectively, yet, strictly at the back of our minds are hidden assumptions, biases and prejudices stemming from one culture or 
the other which shape these theories and determine how we perceive realities, what facts we look at, how we understand and judge their importance and merits. On this note, Dukor (2006) avers that,

Culture guides how people live, what they generally believe and value, how they communicate, and their habits, customs and tastes. It also guides the way people meet the various needs of the society, namely, how goods and services are produced and distributed, how power and decision making are designated, and how deity or gods are represented. Culture therefore prescribes rituals, art forms, entertainment and customs of daily living.

With these, it stands that cultural influences and control over human beings are unquantifiable. And it's numerous, diverse and conflicting contents have largely rendered it a menace to harmonious human existence in Nigeria.

\section{The Philosophical Base of the Argument}

In various discourses, philosophers point at culture as the basis of conflicts in human societies. Heraclitus from his cultural experiences, for instance, teaches that cosmic realities are characterized by 'strife' and 'conflict of opposites'. In congruence with this view, Protagoras argues in his philosophical relativism that as a result of its diversity, culture is the basis of human conflict. This, according to him is because, diverse cultural contents form and foster people's divisive and conflicting perceptions, judgments, understanding and behaviour. Protagoras therefore submits that cultural differences which breed conflicts are products of ethnic convention and not of any natural standard, 
but could be curbed through general state laws in the interest of peaceful and ordered society (Stumpf, 1994).

Adding to these, Whitehead (1991) acknowledges that cultural diversity provides incentives necessary for existence but is responsible for odds or conflicts that call attention in human societies. The philosophical basis of this discourse however become obvious in the views of Rawls that culture is though a necessary space for pursuit of rational and meaningful life but the principal divisive factor in human society, as well as the basis of conflict in the contemporary world (Mackenzie, 2009).

\section{Axiological Panacea to Cultural Conflicts in Nigeria}

Adequate management of diverse Nigerian ethnic groups and their conflicting cultural contents requires responsible, responsive and super servant leadership. This is a leadership with consciousness for functional structures and institutions that are capable of cushioning or managing the stress and tension that result from coexistence of these cultural groups and the changes within them. This is a leadership with eagerness to promote equal socioeconomic and political opportunities for the citizenry. Only such leadership can equally sustain emphasis on positive aspects of diverse cultures, and guarantee inclusive governance that will equitably accommodate all cultural groups. Along this line, the onus lies on Nigerian government to curb cultural hegemony and excesses, and work for the survival of all cultural entities by recognizing positive values in every culture and encouraging cultural dialogue.

In addition to these is great need for a national culture replete with nationalism, loyalty, dedication, integrity, concern for one another, right ideas, skills and tolerance which subsist in diverse Nigerian cultures. The national culture must also be 
characterized by practical human equality, recognition, diverse positive values and practices, truth and goodness. It should as well be fortified with capacity for all round social, intellectual, political, economic, psychological and patriotic development of future Nigerians. Nze (2007) supports this view asserting that;

the only way peoples can be amalgamated meaningfully must be through amalgamation of their ways of life or at least through emphasizing the common denominator of the way they live which adds up to their culture further synthesis into a type of general culture principle.

For general culture to take root or form the interiority of Nigerian citizenry and bridge the present conflicting differences in thought among Nigerians, it has to be embedded in national education curriculum, and must largely cut across the diverse Nigerian environments and positive traditions. Too, the national culture principle has to be promoted through frequent mass media orientation aimed at promoting mutual co-existence and unity among Nigerians. Along this line, mass media orientation should as well recognize and appreciate the positive differences and perceptions among Nigerian cultures which accord confidence and fulfillment to diverse cultural groups, create a sense of parity among them and promote national stability (Aribisala, 2014, Onwubiko, 1991, Stewart, 2000).

Another avenue to reduce conflict in Nigeria is through restructuring the country based on cultural groups. This will go a long way in enabling each cultural nation to exercise a semiautonomy that will preserve her values, traditions and existence. More so, restructuring Nigeria will give each people their desired recognition and reduce conflicts resulting from contradictory cultural values and beliefs that manifest more in present unitary 
system of administration. However, semi-socio-political and economic autonomy should be followed by periodic national conference involving representatives of cultural groups in Nigeria, and aimed at renegotiating national unity. Mutual agreements among cultural groups will indeed reduce cultural extremism, domination, polarization, barriers and ensure compliance of cultural nations in building common Nigerian interest.

\section{Conclusion}

It is in the nature of each cultural group to hold most of her cultural contents as superior and to repudiate those of others as inferior $\left(\mathrm{O}^{\prime}\right.$ Donohue, 1994). More so, a way of life of one cultural group may be repulsive and offensive to another. These are indeed the basis of conflicts in human societies. And exacerbating these conflicts is the fact that these cultures have lots of dissimilar and conflicting contents, and commands the loyalty and patriotism of individual citizenry. With the diversion of loyalty or patriotism to the tribe or sub-nation that results to sabotage of national interest remaining unchecked, the stability and very existence of the country is constantly threatened. Culture is therefore a divisive factor that consistently sparks conflict in Nigerian society (Segun \& Oni, 2010). Its differences destroy common grounds among diverse people sharing the country, and its provocative contents, interpretation, understanding and change create discord among homogenous people.

However, culture is also a unifying force among people with common background (Huntington, 1996). This is as it unites more a homogenous people and people with similar cultural contents. Be that as it may, cultural nations in Nigeria can experience lasting peace and harmony through constant dialogue, Government equal recognition of cultural nations and constant 
emphasis on mutually overlapping similarities and values therein in these cultures.

\section{Gregory Emeka Chinweuba}

Philosophy Unit, General Studies Division

Enugu State University of Science and Technology gregory.chinweuba@esut.edu.ng

\section{References}

Aghamelu, G. F. (2015). Culture and freedom: A Philosophical Examination of the Igbo Traditional Society. Essence Interdisciplinary-International Journal of Philosophy,2,106114.

Amunnadi, C. A. (2012). Negotiation and Mediation. In C. Nnadi \& E. C. Ezeugwu (Eds.), Conflict Prevention and Management Strategies (pp. 52-63). Enugu, Nigeria: His Glory Pub.

Anikwe, F. I. (2014, July-September). Culture and National Development: Challenges \& Prospects. Royalty, 1, 24-26.

Aribisala, F. (2014, December). How to lose the Presidential Election Four Times. Vanguard, p. 17.

Arua, K. C. (2007). Man is Free to be Free and not Free not to be Free. Uche Journal of the Department of Philosophy,13, 113.

Ayatse, F. H., \& Akuva, I. I. (2013). The Origin and Development of Ethnic Politics and its Impact on Post Colonial Governance in Nigeria. European Scientific Journal, 9(17), 178- 189.

Bamikole, L. O. (2008). Democracy in a Multicultural Society. Philosophy and Praxis, 4, 1-20. 
Berger, P. L. (2002). The Cultural Dynamics of Globalization. In

P.L. Berger and S.P. Huntington (Eds.), Many

Globalizations Cultural Diversity in the Contemporary

World (pp. 1-16). New York, USA: Oxford University

Press.

Chinweuba, G. E., \& Ezeugwu, E. C. (2016). Thinking and

Culture: A philosophical Analysis.

International Journal of Innovative Research and Advanced Studies, 3(10), 90-93.

Chinweuba, G. E. (2018). Culture and Corruption: A Critical Analysis of the Basis of Nigerian

Deprave Experience. Unizik Journal of Arts and Humanities, 19(2), 112-130.

Couzen-Hoy, D. (1981). The Critical Circle. California, USA:

University of California Press.

DiMaggio, P. (2000). Social Structure, Institutions, and Cultural Goods: The Case of the United

States. In G. Bradford, et al (Eds.), The Politics of Culture: Policy Perspectives for Indi-

viduals, Institutions and Communities(pp. 38-62). New York, USA: The New Press.

Dukor, M. (2006). Theistic Pansychic Animism of African Medicine. Essence; Interdisciplinary International Journal of Philosophy, 3, vi-xxx.

Ejeh, P. C. (2012). Theories and Basic Concepts of peace. In C. Nnadi \& E. C. Ezeugwu (Eds.), Conflict Prevention and Management Strategies (pp. 1-8). Enugu, Nigeria: His Glory Publications.

Ekiyor, H. A. (2007). The Dynamism of Globalization on Culture: A Case Study of Niger Delta 
In Nigeria. Essence; Interdisciplinary-International Journal of Philosophy, 4, 51-66.

Ezeugwu, E. C. (2012). Ethics and Conflict in Nigeria. In C. Nnadi\& E. C. Ezeugwu (Eds.), Conflict Prevention and Management Strategies (pp.252-268). Enugu, Nigeria: His Glory Publications.

Hobbes, T. (1985). Leviathan. C. B. Macpherson (Trans.), London, England: Penguin.

Ho-Won, J. (2008).Understanding Conflict and Conflict Analysis. Los Angeles, USA: Sage.

Huntington, S. P. (1991). The Third Wave: Democratization in the Late Twentieth Century. Oklahoma, USA: University of Oklahoma Press.

Huntington, S. P. (1996). The Clash of Civilizations and the Remaking of World Order. New York, USA: Simon \& Schuster Paperbacks.

Kanu, A. I. (2010). Towards an African Cultural Renaissance. Professor Bassey Andah Journal of Cultural Studies, 3, 5970.

Langer, A. (2005). Horizontal Inequalities and Violent Group Mobilization in Côte d'Iviore. Oxford Development Studies, 33, 25-45.

Mackenzie, I. (2009). Politics: Key Concepts in Philosophy.New

York, USA: Continuum International Publishing Group.

Michael, B. (2008). The Influence of Information Communications Technologies on the African Philosophy and Culture. Essence Interdisciplinary-International Journal of Philosophy, 5, 87-97.

Nwaozuzu, U. C. (2011). Conflict, Cultural Diversity and Relativism in Contemporary Nigerian Drama: An Apologia. In A.B.C Chiegboka, T. C. Utoh-Ezeajugh\& M. 
S. Ogene (Eds.), The Humanities and Sustainable Development (pp. 124-129). Nimo, Nigeria: Rex Charles \& Patrick.

Nwokolo, B. O., \& Ogenyi, L. C. (2011). Multi-Lingualism: The Bane of Sustainable Development and Cohesion in Nigeria. Journal of Liberal Studies, 14, 104-105.

Nze, C. (2007). Communalism: Bedrock of Patriotism. In I. Odimegwu (Ed.), Perspectives on African Communalism (pp. 491-450). Quebec, Canada: Trafford Publishing.

Obaditan, Y. (2003). Antidotes to Political Violence. Lagos, Nigeria: Kunmi Communications.

Obatala, J. K. (2014, July). Nigeria will gain nothing from Confab, says Tomori. The Guardian, 4-5.

Odimegwu, I. (2006). Health as a cultural Phenomenon. Essence; Interdisciplinary-International Journal of Philosophy, 3, 155-161.

Odimegwu, I. (2008). Integrative Personhood. New Brunswick, USA: Transaction Publishers.

O’Donohue, J. (1994). New Wine and Old Bottles. Uppsala, Sweden: Uppsala University.

Oforegbu, F. C. (2014). Live and Let Live Nigeria: A Philosophical Cum Historical Reflection on Nigeria @ 100. Owerri, Nigeria: Applause B Multi-sects Ltd.

Ogbu K. (1975).Tradition in Revolutionary Change. Ikenga Journal of African Studies, 3(1\&2), 53-58.

Ogbu, K.(1983). African Cultural Development. Enugu, Nigeria: Fourth Dimension Publishers.

Oguejiofor, J. O. (1996). The Influence of Igbo Traditional Religion on the Socio-political Character of the Igbo. Nsukka, Nigeria: Falladu Publishing Company. 
Oguejiofor, J. O. (2009). Is African Worldview responsible for the African predicament? Uche Journal of the Department of Philosophy, 15, 1-13.

Ogugua, P. I. (2005). Understanding Deities in Igbo-African World: A Religio-Philosophical Perspective. Essence Interdisciplinary-International Journal of Philosophy,2, 6491.

Okolo, C. B. (1993). African Social and Political PhilosophySelected Essays. Nsukka, Nigeria: Fulladu Publishing Company.

Olukaode, F. O. (2009). Reproductive Cloning and Culture: Reflection on African Cultural Experience. Essence; Interdisciplinary International Journal of Philosophy, 6, 92102.

Omazu, E. (2010). Africa in the Politics of Dominant Civilization. Unizik Journal of Arts and Humanities, 11, 85-103.

Omoregbe, J. (1991). Knowing Philosophy. Lagos, Nigeria: Joja Educational Research and Pubs.

Onwubiko, O. A. (1991). African Thought and Culture. Enugu, Nigeria: Snaap Press.

Patterson, O. (2000). Taking Culture Seriously: A Framework and an Afro-American Illustration. In L.E. Harrison and S. P. Huntington (Eds.), Culture Matters How Values Shape Human Progress(pp. 202-218). New York, USA: Basic Books.

Segun, J., \& Oni, S.(2010). Politics, Violence, and Culture: The Ebira Tao Nigerian Experience. Professor Bassey Andah Journal of Cultural Studies, 3, 71-94.

Senghaas, D. (2002). The Clash within Civilizations. London, England: Routledge. 
Stumpf, S. E. (1994). Philosophy History \& Problems. New York, USA: McGraw-Hill Inc.

Ugwu, E. C. (2012). Culture, Human Resource Management and Local Council Administration in Nigeria: A study of Local Government Areas in Enugu State. Ikoro: Journal of Institute of African Studies, 9,132-162.

United Nations Development Programme (UNDP). (2004). Human Development Report. New York, USA: United Nations.

Whitehead, A. (1991). Science and the Modern World. In P. W. Goetz (Ed.), Great Books (p.233). Chicago, USA: Encyclopedia Britannica Inc., Vol. 55. 